Pamiętnik Literacki 2012, 4, s. 101-113
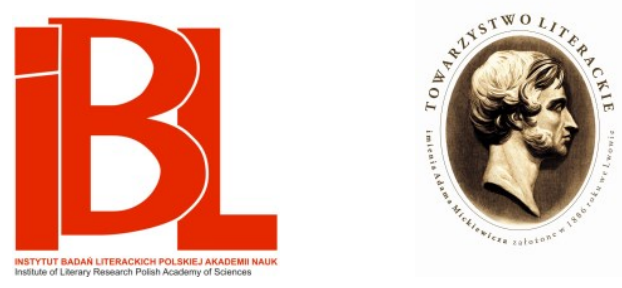

11 września 2001 w poezji (Szymborska,

Lipska, Hartwig)

Katarzyna Wądolny-Tatar 
Pamiętnik Literacki CIII, 2012, z. 4

PL ISSN 0031-0514

KATARZYNA WĄDOLNY-TATAR

(Uniwersytet Pedagogiczny w Krakowie)

\section{WRZEŚNIA 2001 W POEZJI (SZYMBORSKA, LIPSKA, HARTWIG)}

Precyzyjnie oznaczane daty wydarzeń historycznych, mające nie tylko roczną sygnaturę, ale także miesięczną i dzienną, nadają zajściu określoną wagę i zawsze na nią wskazują. Umożliwiają i uruchamiają mentalny powrót, rocznicowe obchody, rozmaite formy upamiętniania, bo data z natury rzeczy nie przystaje do teraźniejszości. Są też jak imię własne, identyfikujące, lecz również szyfrujące w nazwie grupę cech, zależności między nimi i odniesienia, składające się na fakt lub zespół faktów, historycznie i powierzchniowo wyrażonych znakiem-datą. W jakimś sensie nadanie daty oddala od wydarzenia i jego autentyczności, z konieczności zastępowanego jakby niekompletnymi przedstawieniami, warunkowanymi długością ludzkiego życia (uczestników, świadków), pamięcią, punktem widzenia, językiem i sposobami komunikacji charakterystycznymi dla konkretnych czasów, co przecież oznacza selektywność, fragmentaryczność, subiektywizm opisu.

Niedawno minęła dekada od dramatycznych wydarzeń ujmowanych pod wspólną datą: 11 września 2001. Seria terrorystycznych ataków zachwiała amerykańsko-europejską stabilizacją, odebrała - zaatakowanym wówczas - chwilowe złudzenie nieszczęśliwego zbiegu okoliczności, przypadku, bo odsłoniła zaplanowany przebieg działań agresora. Momentalnie też ustanowiła centrum świata, w którym rozgrywały się absorbujące wszystkich wypadki. Tragiczna cezura spowodowała również potrzebę ,przepracowania” traumy, weryfikację faktów, konieczność podsumowań, rozliczeń i zmian w globalnej polityce czy ekonomii, ale także wyzwoliła najróżniejsze reakcje w kulturze, filozofii i literaturze.

Powstały powieści, których kanwą były historyczne już dziś wydarzenia: Jonathana Safrana Foera Strasznie głośno, niesamowicie blisko (główną postacią jest tu dziecięcy bohater, kilkuletni Oskar) ${ }^{1}$, Dona DeLillo Spadając ${ }^{2}$, Johna Updike'a Terrorysta ${ }^{3}$ czy Frédérica Beigbedera Windows on the World ${ }^{4}$. W tej ostatniej podmiot mówiący, funkcjonujący jakby na granicy życia i śmieci, relacjonuje dramatyczne wypadki z wnętrza zapadającego się budynku. Mężczyzna, który znalazł się tam przypadkowo, i towarzyszący mu dwaj mali synowie - podzielili

J. S. F o e r, Strasznie głośno, niesamowicie blisko. Przeł. Z. B a t k o. Warszawa 2007.

2 D. D e L i 11 o, Spadając. Przeł. R. S u d ó ł. Warszawa 2008. Ukazała się książka o klasykach pisarstwa amerykańskiego: Don DeLillo. Red. M. Paryż. Warszawa 2012.

3 J. U p d i k e, Terrorysta. Przeł. J. K o zło w s k i. Poznań 2007.

4 F. B e i g b e d e r, Windows on the World. Przeł. M. K a m i ń s k a-M a u rug e o n. Warszawa 2004. 
los wielu ofiar. W powieści często tenże narrator, obdarzony sylleptyczną podmiotowością i szczególną przedwiedzą, zapowiada tragedię (,W ciągu następnych minut World Trade Center, świątynia ateizmu i międzynarodowego zysku, przemieni się stopniowo w prowizoryczny kościół" 5). Sytuacja uwięzionych w budynkach kojarzona jest przez osobę mówiącą z pobytem w hitlerowskim obozie zagłady w Auschwitz, sarkastycznie określa on pomieszczenie, z którego nie może się wydostać - jako ,komorę gazową de luxe" ". Antecedencyjna narracja przekracza horyzont zdarzeń zakończonych (realnie):

Ratownicy nigdy do nas nie dotarli. Nie widzieliście nas w telewizji. Nikt nie sfotografował naszych twarzy. Wszystko, co wam po nas pozostało, to nasze rozedrgane postacie uczepione elewacji, ciała w szybkim locie, ręce wymachujące w eterze szmatami, białymi niczym kawałki chmur. Ogłuszający dźwięk upadków w filmie dokumentalnym braci Naudetów. Jedyny film o tragedii jest dziełem Francuzów.

Ale nie pokazali oni spadających ochłapów ludzkich, fontann krwi, stali, ciał i plastiku stopionych w jedno. Wy nie czuliście smrodu spalonych kabli elektrycznych, tego smrodu krótkiego spięcia, pomnożonego przez sto tysięcy woltów. Nie słyszeliście zwierzęcego ryku, kwiku świń o podrzynanych gardłach, cieląt ćwiartowanych żywcem, choć to nie były cielęta, tylko ludzkie ciała błagające o życie ${ }^{7}$.

Do czasu ,przed” atakiem i ,po” nim odniosła się w emocjonalnej narracji znana dziennikarka Oriana Fallaci ${ }^{8}$, wzbogacając swoją wypowiedź wiedzą o wielu ważnych osobach publicznych. Ukazały się też polskie komentarze i omówienia9 . Wreszcie wobec nowej sytuacji określiły się także filozofia, antropologia, socjologia. Francuski socjolog i filozof kultury Jean Baudrillard, charakteryzując istotę fundamentalizmu, w zbiorze filozoficznych esejów napisał:

Żywotna przeciwpotęga w zwarciu z potęgą śmierci systemu. Potęga wyzwania rzuconego globalizacji rozpuszczonej w morzu cyrkulacji i wymiany. Potęga nieredukowalnego wyjątku, przejawiającego się tym gwałtowniej, im dalej sięga hegemonia systemu - aż do wydarzenia takiego jak 11 września, które przerywa ten wyścig, nie rozstrzygając jednak kryjącego się za nim antagonizmu, lecz nadając mu wymiar symboliczny ${ }^{10}$.

Źródeł ekscesywnej przemocy upatruje filozof w asymetrii kulturowej, ale również politycznej, ekonomicznej. Wydaje się jednak, że sytuowanie „siebie”

5 Ibidem, s. 117.

${ }^{6}$ Ibidem, s. 247.

7 Ibidem, s. 235. W innym miejscu autor wskazuje na literaturę francuską jako kultywującą „tradycję nieposłuszeństwa” (s. 267).

8 O. F a 11 a c i, Wściekłość i duma. Przeł. K. Hejw o w ski. Warszawa 2003. Zob. też 11 września 2001. Jak to się stato i co dalej? Red. J. F. Hoge Jr., G. Rose. Przeł. M. A n t o s i e w i c z [i in.]. Warszawa 2001. - B. W o o d w a r d, Wojna Bush. Przeł. W. J e ż e w s k i. Warszawa 2003. - G. S o r o s, Bańka amerykańskiej supremacji. Przeł. D. C h y l iń s k a. Kraków 2004.

9 Zob. S. K r aj s k i, Atakna Amerykę. Fakty. Komentarze. Wnioski. Warszawa 2001. - Świat po 11 września 2001 roku. Red. K. Gładkowski. Współpr. B. C z o p, A. H ołu b, A. O rg a n iści a k-Krzykowska. Olsztyn 2003 (zbiór studiów politologicznych na temat aktualnej społeczno-politycznej sytuacji na świecie po wrześniowym ataku). - M. Str z a ła, Dzień, w którym zgasto słońce nad Manhattanem. 11 września 2001. Co naprawdę wtedy się wydarzyło? Kraków 2005 (książka oparta na relacjach naocznych świadków). - M. P a tk ow ski, Czarny wtorek. Warszawa 2007 (opis także polskich ofiar ataku na WTC).

10 J. B a u d rill a r d, Hipotezy na temat terroryzmu. W: Duch terroryzmu. Requiem dla Twin Towers. Przeł. R. L i s. Warszawa 2005, s. 64. 
i społeczeństwa, które się reprezentuje - w jakimś centrum, stanowi niezbywalny atrybut ludzkiego myślenia i bycia w świecie.

W jednym $\mathrm{z}$ wywiadów Jacques Derrida ${ }^{11}$ mówił o militarnej i finansowej przewidywalności ataku, możliwościach obserwacji przepływu i gromadzenia kapitału. Zaistniałe wypadki filozof uznał za potencjalny scenariusz, który się zrealizował ${ }^{12}$, w konsekwencji postulował opis zmienionej polaryzacji świata, redefinicję wojny i tolerancji. Derrida w komentarzach odnosił się do amerykańskiej i europejskiej ,polityki snów”, stwierdził:

Sen, o którym mówiłem, jest snem myśli, a nie aktualną zbiorową fantazją o bezpieczeństwie, patriotyzmie czy zemście. Musimy przerwać ten koszmar, przeciwstawić się mu polityką przebudzenia. Musimy się przebudzić z tego snu ${ }^{13}$.

Wstrząsające wydarzenia filozof rozpatrywał w kategoriach traumy i autoodporności jednostkowej czy społecznej. „Dekonstruując” terroryzm wyjaśniał:

dana tożsamość może nie być doskonale homogeniczna, gdyż wchłania w siebie ślady tego, co bezpośrednio wyklucza. Dekonstrukcja poszukuje tych śladów i wykorzystuje je, aby dać głos temu, co nie pasuje do dominującego zestawu inkluzji i ekskluzji ${ }^{14}$.

Dialektyka śladu i obecności ujawnia się - zdaniem Derridy - także w języku i w ludzkiej kategoryzacji świata. Autorka komentująca stanowisko filozofa odnosi je również do interesujących nas wydarzeń i ich daty:

Owe ślady, przy których upiera się dekonstrukcja, są rozproszone (disseminated) przede wszystkim w języku. Derrida rozpoczyna swoją interpretację ataków terrorystycznych z 11 września od zastanowienia się nad sensem nazwania takiego wydarzenia za pomocą daty. Cóż oznacza takie nazwanie wydarzenia, pyta, kiedy miejsce i znaczenie tego wydarzenia pozostają niewysłowione? Data 11 września jest w kółko powtarzana, jak gdyby jego partykularność była tak absolutna, że nie mogłaby być utożsamiona z jakąkolwiek generalizacją ${ }^{15}$.

W jednej z wcześniejszych publikacji Derrida przyglądał się zewnętrznemu (jawnemu) oraz wewnętrznemu (ukrytemu) datowaniu w tekście literackim na przykładzie poezji Paula Celana. Zwłaszcza w drugim przypadku zachodziło zacieranie, kryptonimowanie daty, w obu zaś - jej użycie w utworze powodowało upoetycznienie sygnatury czasu, zniesienie różnicy między rzeczywistością a fikcyjnością, w zasadzie natomiast nieprzynależność całkowitą daty do żadnej z tych sfer. Jeśli można było mówić o empirii, pozwalało na nią to hermeneutyczne zdarzenie wiersza, o czym Derrida pisał: ,tym, co staje się czytelne, nie jest s a m a data, ale poetyckie doświadczenie daty; to, co ta je dna data narzuca nam

11 J. D e r r i d a, U. R a u $1 \mathrm{ff}$, Nikt nie jest bez winy. Rozmowa z Jacques'em Derrida o filozofii w obliczu terroryzmu. Przeł. B. M a ł c z y ń s k i. W zb.: Czytanie Derridy. Red. B. Małczyński, R. Włodarczyk. Wrocław 2005, s. 89-91. Pierwotnie wywiad ukazał się na łamach „Sueddeutsche Zeitung" (2001, nr z 24 IX).

${ }_{12}$ Reakcja taka jest przez psychologów określana mianem „błędu wstecznej pewności” i definiowana jako skłonność do sądzenia po zajściu, że było się w stanie je przewidzieć.

${ }_{13}$ D e r rida, R a u lff, op. cit., s. 90.

${ }^{14}$ Filozofia w czasach terroru. Rozmowy z Jürgenem Habermasem i Jacques'em Derrida. Przeprowadziła i komentarzami opatrzyła G. B o r r a d or i. Przeł. A. K a r a l u s, M. Ki l a n ows k i, B. O r l e w s k i. Red. A. Szahaj. Warszawa 2008, s. 178.

${ }^{15}$ Ibidem, S. 179. 
w naszym stosunku do niej, poetyckie poszukiwanie" ${ }^{16}$; albo w innym miejscu: „Data interesuje nas więc jako cięcie lub nacięcie, jakie wiersz nosi na swoim korpusie, taka pamięć, czasami wiele pamięci w jednej, znamię pochodzenia, miejsca i czasu" ${ }^{17}$. Występowanie i funkcje daty w dziele poetyckim francuski filozof literatury objaśnia poprzez hebrajski termin „szibbolet”, którego wielość znaczeń w językach fenickich, judeo-aramejskich i syryjskich (,,rzeka”, „strumień”, „gałązka oliwna”, „kłos pszenicy”) zawsze uwydatnia jakąś łączność ze źródłem, początkiem, nasieniem, także rozwój, ruch, rozprzestrzenianie się; określenie to - zdaniem Derridy - dobrze oddaje zależności między datą a wydarzeniem, jakie ta sygnuje. Każda data ma więc swój ,szibbolet”, czyli „, świetlisty, błyszczący rój przypisów, wiele rozpoznawczych znaków, służących do rozszyfrowania i wyjaśnienia zagadki” ${ }^{18}$. W ,szibboletowej” konstelacji dla daty 11 września 2001 znajdą się również polskie wiersze jako indywidualne doświadczenia historii i języka.

Osobność bezprecedensowych wydarzeń sygnalizowana jest poprzez użycie daty również w polskiej liryce ${ }^{19}$. Trzy poetyckie odsłony zajść związanych z atakiem na World Trade Center, o których będzie mowa, to utwory Wisławy Szymborskiej Fotografia z 11 września ${ }^{20}$, Ewy Lipskiej 11 września $2001^{21}$ i Julii Hartwig Wieże $e^{22}$. Mocny poetycki trójgłos jest świadectwem uniwersalności poprzez pojedynczość i indywidualność reakcji poetek. Teksty właśnie w takiej kolejności można rozpatrywać w aspekcie temporalnym - jako rzeczywistość ujętą „tu i teraz” (Szymborska), „niedługo potem” (Lipska), ,jakiś czas później” (Hartwig), uruchamiają one różne strategie twórcze uobecniania zdarzeń, różny dystans wobec nich.

Często przywoływany przez badaczy literatury wiersz Fotografia z 11 września już w tytule eksponuje medium. Relacje: ,ja” - opisywana rzeczywistość, dają się ująć w minimalnym dystansie, w bieżącej zdarzeniowości, w (foto)reporterskiej bliskości, prowokującej do utrwalenia na zdjęciu. Ludzie wyskakują z różnych pięter płonących wieżowców i w niewielkich odstępach czasowych, jakby na oczach „ja”, wchodzą w powietrzną przestrzeń, a zarazem w obręb przedstawionej sytuacji lirycznej - i w tej ostatniej naprawdę pozostaną zapisani. Zależność (wynikająca z wagi i skali zdarzenia, sugestywności fotografii jako medium oraz „tej” ukonkretnianej w wierszu) i niezależność (oznaczająca pewną osobność kodu werbalnego, a także demiurgiczne możliwości poety) podmiotu ujawnia się w klauzuli utworu. Fragment funkcjonuje już w ramach mediacji:

\footnotetext{
Tylko dwie rzeczy mogę dla nich zrobić opisać ten lot i nie dodawać ostatniego zdania.
}

16 J. D e r r i d a, Szibbolet dla Paula Celana. Przeł. A. D z i a d e k. Bytom 2000, s. 9.

17 Ibidem, s. 21.

18 Ibidem, s. 20.

19 Wiersze dotyczące tragedii nowojorskiej - oprócz analizowanych tutaj - możemy odnaleźć w twórczości J. Barana, J. Szubera, B. Gruszki-Zych, L. Latus i innych.

${ }^{20}$ W. S z y m b or s k a, Fotografia z 11 września. W: Chwila. Kraków 2002.

${ }^{21}$ E. L i p s k a, 11 września 2001. W: Ja. Kraków 2003, s. 31. Wiersz został zamieszczony również w dwujęzycznym zbiorze pod znamiennym tytułem Miasteczko Świat (Przeł. na język ros. A. R o itm a n. Posł. J. P o m i a n ow sk i. Kraków 2007, s. 24).

${ }_{22}$ J. H a r tw ig, Wieże. W: Bez pożegnania. Warszawa 2004. 
Szymborska uruchamia w wierszu i aktywizuje u odbiorcy jednocześnie dwa kody: słowny i obrazowy. Werbalne projektowanie obrazu podlega uszczegółowieniu w procesie lektury. Fotografia dostępna jest tylko poprzez słowo, opis pozwala naszkicować jej zawartość i sam jej dotyczy. Zdarzenie uchwycone zostaje przy użyciu dynamiki słów, statyki fotograficznego obrazu. Wyraźna jest tu procesualność „opisu lotu” („Każdy to jeszcze całość”; „Jest dosyć czasu, / żeby [...]”; „Są ciągle jeszcze w zasięgu powietrza, / w obrębie miejsc, / które się właśnie otwarły"). Momentalna organizacja przestrzenno-temporalna opiera się na konstrukcji a u odbiorcy na intensywnym wrażeniu - ,tu i teraz”. „Tyrania chwili” trwa! ${ }^{23}$ Towarzyszy jej złudna nadzieja, że fotografia ,zapobiegnie” upadkowi (,Fotografia powstrzymała ich przy życiu, / a teraz przechowuje / nad ziemią ku ziemi"). „Osobiste" twarze, drobne przedmioty wypadające z kieszeni skaczących, podkreślają indywidualny wymiar zbiorowej tragedii. Wertykalna siła ruchu, rozpaczliwa kinestetyka postaci jako ciążenie w dół zawiera w sobie sugestię nieodwracalnego finału. „Otwarcie miejsc" możliwe jest tylko na fotografii i paradoksalnie mówiący podmiot w finalnej części wiersza poprzez poniechanie „ostatniego zdania” stara się sprostać temu otwarciu. Gest podmiotu-twórcy zdradza jednak pewną bezradność, złagodzoną potencją utrwalania przynależną słowu. Możliwe, że: „Heroizm Szymborskiej polega na tym, iż za wszelką cenę chce widzieć jedynie fotografię, na której ów »lot « nigdy się nie skończy" ${ }^{24}$. Poetka, afirmująca w swej twórczości cud istnienia, pozostaje wierna tej zasadzie. Podwójna kreacja - za sprawą wiersza i fotografii - przeczy realności do tego stopnia, że lekceważy następstwo przyczynowo-skutkowe, wszak konsekwencją tego lotu powinien być tragiczny upadek. Tymczasem u poetki chwila dąży ku eonowi ${ }^{25}$.

Małgorzata Czermińska, uznając utwór Szymborskiej za ekfrazę, stwierdza:

Wiersz Fotografia z 11 września opisuje powszechnie znaną fotografię prasową, ukazującą drobne sylwetki ludzi skaczących z płonącego wieżowca, jedno z niezliczonych przedstawień terrorystycznego zamachu w Nowym Jorku. Stylistycznie rzecz biorąc, nie jest to opis przedmiotu, ale dynamiczne opowiadanie o rozgrywającym się właśnie zdarzeniu ${ }^{26}$.

Ekfraza nie jest tu „celem samym w sobie, ale środkiem do innego celu, którym jest jakaś refleksja pobudzona przez to dzieło" ${ }^{27}$. Jej zastosowanie stanowi jednoczesny zabieg interpretacyjny. Fotografia - jako mem kultury - wprowadzona w przestrzeń między twórcą a czytelnikiem pełni funkcję pośrednio ewokowanego nośnika informacji. Z jednej strony, możemy mówić o niesamodzielności i degradacji opisu uzależnionego od fotografii, z drugiej - słowna prezentacja (rzekome-

${ }^{23}$ Semantyczna kontaminacja i transformacja tytułu książki E. T. E ri k s e n a Tyrania chwili. Szybko i wolno plynacy czas w erze informacji (Przeł. G. S o kół. Wyd. 1, dodruk. Warszawa 2004) i znanej eksklamacji z Fausta J. W. G o e th e g o.

${ }^{24}$ C. Z a l e w s k i, Terror (z) fotografii. Nowoczesna przemoc w ujęciu Rafała Wojaczka i Wisławy Szymborskiej. W: Pragnienie, poznanie, przemijanie. Fotograficzne reprezentacje w literaturze polskiej. Kraków 2010, s. 107.

${ }_{25}$ Poetyckie projekcje czasu, również na podstawie zbioru Szymborskiej Chwila, opisuje D. O p a c k a - W a 1 a s e k (Chwile i eony. Obrazy czasu w polskiej poezji drugiej połowy XX wieku. Katowice 2005).

${ }^{26}$ M. C z e r m iń s k a, Ekfrazy w poezji Wisławy Szymborskiej. ,Teksty Drugie” 2003, nr 2/3, s. 241.

${ }^{27}$ Ibidem. 
go? $)^{28}$ przekazu wizualnego nie wychodzi poza literaturę. Dokonuje się chwilowe zrównanie logocentryzmu i okulocentryzmu. Cezary Zalewski przygląda się utworowi Szymborskiej także w kontekście referencji, jakie ustala dla fotografii literatura: „Jest [...] zastanawiające, iż poeci próbujący przedstawić akty przemocy obecne w życiu społecznym również sięgają po odpowiednie zdjęcia”. I wylicza:

po pierwsze, obrazy te już funkcjonują w przestrzeni odbioru, zatem nawiązanie do nich dokona jedynie wzmocnienia układu literackiej komunikacji. Paradoksalnie, dzieje się tak nawet wtedy, kiedy wiersz stara się zakwestionować tę „,władzę” zdjęcia nad pamięcią odbiorcy. Po drugie, fotografie te umożliwiają wprowadzenie dyskursu, w którym staje się wielostronny i głęboki namysł nad przemocą ${ }^{29}$.

Konkretność fotografii dostępnej poprzez wiersz - wobec licznych medialnych reprezentacji nowojorskiego zamachu - bywa jednak kwestionowana czy anulowana przez zmienny ilustracyjny kontekst. W antologii Pisane świattem. Antologia poezji inspirowanej fotografia w sąsiedztwie wiersza Szymborskiej pojawia się „obca” fotografia, wykonana w latach siedemdziesiątych ubiegłego wieku. Autorzy antologii mówią o łączeniu artefaktów: „Trzeba było do kolejnych wierszy dobrać fotografie w taki sposób, aby stworzyć im jedynie asocjacyjne tło, wskazując na wzajemne relacje" ${ }^{30}$. Włączenie innego obrazu w sugerowany porządek analityczno-interpretacyjny nie zmienia podstawowej funkcji fotografii-obrazu w wierszu. Dzieje się tak głównie dlatego, że Szymborska ,posługuje się [...] fotografią, aby wychwycić ten nieoczekiwany moment, w którym życie miało »jeszcze« przewagę nad śmiercią" ${ }^{31}$. Zabieg osłabia świadomość nieuniknionego także u odbiorcy wiersza. Poetka przyjmuje kontrpostawę wobec biegu spraw, próbując zanegować nawet prawa fizyki czy biologii, postępując jakby wbrew zasadom uznawanym w mediach:

im bardziej śmierć człowieka odbiega od przypisanej mu biologicznymi uwarunkowaniami egzystencji, tym jest bardziej interesująca dla mediów. [...] Wydaje się, iż ta obsceniczność mediów stanowi nową zastępczą strategię oswajania śmierci ${ }^{32}$.

O bezpośrednim związku wiersza Ewy Lipskiej z wydarzeniami 11 września 2001 świadczy jedynie tytuł składający się z pełnej daty. Wyraźna sygnalizacja zależności i odniesienia nie udaremnia wszakże odczytywania i interpretacji wiersza w kategoriach uniwersalnych. Liryk nie stanowi deskrypcji dramatycznych wydarzeń, dotyczy projektowanych reakcji wybranych grup na przebieg wypadków. W kręgu reagujących znajdują się: „Poeci wywiadowcy świątobliwi podatnicy / pieśniarze jubilerzy", lecz także krawiec - i tej postaci pośrednio przypisana zostaje mądrość życiowa. Identyfikacja głośno odpowiadających wskazuje na osoby

${ }^{28}$ Trudno oprzeć się wrażeniu, że mamy do czynienia z podwójnym fingowaniem - fikcją fotograficzną dostępną poprzez fikcję literacką. Niełatwo również ustalić „konkretność” zdjęcia „wykorzystanego" przez Szymborską, która posłużyła się tutaj pozorną ekfrazą.

29 Z a lew ski, op. cit., s. 100.

${ }^{30}$ B. M a re k, Z. H a r a s m, T. K a li śc i a k, posłowie w: Pisane świattem. Antologia poezji inspirowanej fotografia. Koncepcja, oprac., wybór wierszy i fotografii B. M a r e k, Z. H ar a s y m, T. K a 1 i ś c i a k. Olszanica 2007, s. 183.

${ }^{31} \mathrm{Z}$ a le w s ki, op. cit., s. 107.

32 A. O g o n ow s k a, Twórcze metafory medialne. Zarys problemu w ujęciu kognitywno-kulturowym na przyktadzie teorii Jeana Baudrillarda. W: Twórcze metafory medialne. BaudrillardMcLuhan-Goffman. Kraków 2010, s. 84. 
reprezentujące różne środowiska, ale może też być peryfrastycznym (i wtedy metaforycznym) określeniem ludzi słowa i pióra (w tym twórców literatury). Wyodrębnione w osobnym wersie zestawienie ,pieśniarze jubilerzy” uznać trzeba za metaforę apozycyjną, zwłaszcza w kontekście późniejszego fragmentu rozwijającego to ujęcie:

\section{Jubilerzy starannie będą szlifować fakty. Odpowiedni kształt. Odpowiedni połysk. Precyzyjna biżuteria katastrofy.}

Obróbka faktów staje się częścią jubilerskiej roboty, a jej efektem jest oczekiwany kształt i połysk „biżuterii katastrofy”. Komunikowanie o wydarzeniach oscyluje między opisem a kreacją, oznacza jednocześnie konstruowanie opinii, ocen, kontekstualizację, emocjonalizację, manipulację ${ }^{33}$. Z pewnością teleologia selekcji faktów, sąsiedztwo przekazów słownych i obrazowych decyduje o charakterze informacji. Nie bez znaczenia są też „ozdoby” tropów, zwłaszcza w kontekście tropologii jako koncepcji tekstu, uzależnionej od przyjętego repertuaru środków i przekształceń semantycznych. Podmiot liryczny zamyka pierwszą część wypowiedzi ironicznym komentarzem: „Naturalnie / wszyscy poddawać się będą do druku". Hegemonia druku i kuszące zdeponowanie własnego śladu w upublicznionej treści - uwiarygodni przekaz. Paradoksalnie poetka brzmi w ,jubilerskim” chórze, ironicznie (auto)komunikując o własnym położeniu. Dwuznaczność stwierdzenia otwiera frazeologiczną opalizację sensu między „podawać (się) za kogoś” i ,poddawać się” (karze, kontroli, opiece).

$\mathrm{Na}$ diatetyczność podobnych struktur predykatowo-argumentowych, jak również na użycie metaforyki apozycyjnej oraz eliptyczność poezji Lipskiej wielokrotnie zwraca uwagę Krzysztof Skibski ${ }^{34}$. Zabiegi te składają się na zespół idiolektalnych cech i inklinacji artystycznych autorki tomiku Ja. Z oglądu twórczości Lipskiej wyprowadza Adam Poprawa trzy zasady dynamiki języka poetyckiego: pewności (interpunkcyjnej, prozodycznej, graficznej), gęstości metaforycznej (postawangardowej, ponadrealistycznej), sprawdzania (języków, idei, kultury) ${ }^{35}$. Sprawdzanie kodów świata odbywa się także w analizowanym tu utworze, podmiot poddaje się też (auto)kontroli.

Jakby na drugim biegunie spolaryzowanych $\mathrm{w}$ wierszu reakcji znajduje się inny rzemieślnik - krawiec, z którym znajomość podmiot mówiący podkreśla przez zaimek dzierżawczy „mój”. Prowadzony z nim cichy dialog „ściegiem płaskim” również sugeruje jakąś zażyłość, porozumienie, wspólność poglądów. Wykluczenie postaci z grupy poprzedniej jest jej indywidualizacją. Wypowiedź krawca, choć podana w mowie zależnej, zachowuje ślady niezależności, ponieważ posługuje się on językiem właściwym uprawianemu przezeń rzemiosłu (,,świat się spruł”), jego

${ }^{33}$ Rzeczywistym doniesieniom prasowym o nowojorskich wydarzeniach przygląda się Z. K lo ch (Punkt widzenia i ideologia: o relacjach prasowych na temat ataku na World Trade Center. W zb.: Punkt widzenia w tekście i w dyskursie. Red. J. Bartmiński, S. Niebrzegowska-Bartmińska, R. Nycz. Lublin 2004). Naczelną kategorią staje się dla badacza punkt widzenia.

${ }^{34}$ Omawiany utwór służy w książce K. S k i b s k i e g o Antropologia wierszem. Język poetycki Ewy Lipskiej (Poznań 2008, s. 148) jako egzemplifikacja metafor apozycyjnych.

${ }_{35}$ A. P o p r a w a, Poezja, świat i inne niepewniki. W zb.: Nic nie jest pewne. O twórczości Ewy Lipskiej. Red. A. Morawiec, B. Wolska. Łódź 2005, s. 190. 
słowa wyrażają także totalność zmiany, całkowitość destrukcji (,spruł” to przecież nie tylko „rozpruł”). W klauzuli utworu pojawia się na prawach ironii dwuwers personifikujący narzędzie krawieckie: „A maszyna do szycia / zjadliwie się śmieje”. Maszyna (podobnie jak całe komputerowo-cyfrowe i „AGD-owskie rekwizytorium" ${ }^{36}$ ) reprezentuje tu świat zdobyczy techniki, który jakby wymyka się spod ludzkiej kontroli, współtworząc rzeczywistość symulakrów - syntetycznych światoobrazów bez odniesienia do realności nie reprezentowanej przez nie - umożliwiając automatyzację zła, sankcjonując współczesny manicheizm. Tylko cud dialogu i porozumienia nie jest mechaniczny ${ }^{37}$. Skibski, analizując dynamiczną metaforykę Lipskiej w zakresie układów i połączeń metaforycznych, konkluduje w odniesieniu do wiersza 11 września 2001:

Zderzenie w tekście dwu perspektyw uruchamiających pola pojęciowe przyporządkowuje elementy składowe tekstu, tworząc rodzaj mozaiki o silnym zabarwieniu ironicznym. Pierwsze pole, związane z czynnościami jubilera przygotowującego biżuterię, fundowane przez metonimiczne ujęcie zbrodni, aktywne w percepcji ludzi nastawionych na orzekanie o rzeczywistości w sposób autorytatywny i wymagający popularności. [...] Drugie pole, związane z czynnościami i warsztatem krawca, skonstruowane zostaje na zasadzie kontrastu, z położeniem akcentu na relatywność i niejasność mechanizmu oceny zjawisk niezwykłych i tragicznych ${ }^{38}$.

Wierszom Lipskiej stale towarzyszy refleksja na temat kultury elektronicznej i multimedialnej poddanej oglądowi ${ }^{39}$. Skibski uważa, że utwory poetki z lat 1994-2005 stanowią zdystansowany komentarz do rzeczywistości. O wierszach $\mathrm{z}$ tego czasu pisze:

podmiot u Lipskiej mocuje się z tematami najważniejszymi, jak miłość, zło, Bóg, życie i poezja. Bezkompromisowość oglądu świata w nowych tekstach, przez [...] syntetyzowanie fraz, a także wielopoziomowy komentarz do człowieka współczesnego, przeradza się w klasycyzujący maksymalizm - postawę wyjątkowo stosowną wobec obserwowanych zmian i powtórzeń ${ }^{40}$.

Badacz dostrzega, że kategorie z wczesnych wierszy poetki (dom, dziecko, choroba, podróż) nie dominują już w poetyckim obrazowaniu świata. Na ewolucję fundamentalnych motywów w twórczości Lipskiej wskazuje też Grzegorz Olszań$\mathrm{ski}^{41}$. Poetyka mortalna zmienia u autorki 11 września 2001 wymiary, wyrażając się zarówno w mikro-, jak i w makroskali.

Tom $J a$ postrzegany bywa jako introspektywny i wspomnieniowy. Część zawartych w nim wierszy może stanowić pokłosie amerykańskich (i w ogóle wszel-

${ }^{36}$ Ibidem, s. 192. Zob. też J. K le j n o c k i, Zanim zadrży ci ręka nad klawiszem Enter... O jednym wierszu Ewy Lipskiej. W zb.: jw. Autor analizuje wiersz Naciśnij Enter z tomu Sklepy zoologiczne (Kraków 2001).

${ }_{37}$ Korzystam tu pośrednio ze sformułowania użytego w tytule książki A. B u r zyńs ki ej Mechanika cudu. Strategie metateatralne w polskiej dramaturgii awangardowej (Kraków 2005), mimo że książka ta dotyczy innych kwestii niż poruszane w artykule.

${ }^{38} \mathrm{~S}$ k ib s ki, op. cit., s. 196.

39 J. Wols k i (Ewa Lipska sceptyczna. W zb.: Nic nie jest pewne) podkreśla sceptycyzm poezji autorki 11 września 2001, traktując go jako odpowiedź na trudne, groteskowe, ułomne, ulotne, przepełnione sprzecznościami życie, chaos współczesnej cywilizacji.

${ }^{40} \mathrm{~S}$ kib ski, op. cit., s. 53.

${ }^{41}$ G. O $1 \mathrm{~s}$ z a ń s k i, Śmierć udomowiona. Szkice o wyobraźni poetyckiej Ewy Lipskiej. Katowice 2006 . 
kich) podróży Lipskiej, o których pisze Robert Mielhorski ${ }^{42}$. Wydaje się jednak, że poetka przewrotnie tytułuje swój tom, gdyż nie znajdujemy w nim przejawów szczególnej ekspresji indywidualnej. Można przyznać więc rację Leokadii Hull, która mówi:

Przestrzeń intymna podlega [...] estetycznemu samoograniczeniu, nadal powściągana potrzebą dyskrecji - $\mathrm{u}$ artystki, której sztuka jest pozbawiona egotyzmu. Stąd manifestowane w tytule ,ja" czytać można też w znaczeniu autoironicznym, jako grę z konwencjonalnym wyobrażeniem o tak zwanej liryce kobiecej. Konstrukcja podmiotowego ,ja” w jej utworach nie jest nacechowana poetyką osobistego wyznania, lecz ma charakter otwarty, dotyka tego, co wspólne dla ludzkiej egzystencji. Przechodzi więc niejako w „my”, poetycko rozpoznawane zawsze w szerszych kontekstach miejsca i czasu ${ }^{43}$.

Podobnie jako część „lektury istnienia” Janusz Pasterski postrzega omawiany tu wiersz Lipskiej i stwierdza: „To człowiek i jego dynamiczna, zmieniająca się podmiotowość $\mathrm{w}$ przewartościowanym świecie stanowi zasadniczy [...] problem tej poezji" ${ }^{44}$.

Utwór Wieże Julii Hartwig, pochodzący ze zbioru Bez pożegnania, wpisuje się w amerykańskie doświadczenia poetki, których reminiscencje zawarła ona także we wcześniejszych tomach (np. w Wierszach amerykańskich ${ }^{45}$ ). Wypowiedź podmiotu jest kontestacją panoramicznego obrazu obserwowanego ex post. Pierwsze fragmenty przynoszą niemal narracyjny opis jednego z brooklińskich bulwarów, z którego otwiera się interesująca perspektywa miasta, stąd uwiecznianego na licznych fotografiach przez turystów, a także tego samego bulwaru jako miejsca spotkań i odpoczynku w porze lunchu. Trwałość pewnych nawyków, powrót do przyzwyczajeń gwarantują zwykłą codzienność, normalność, stabilizację: „Przychodzą tu nadal, / bo choć znikły dwie najwyższe wieże, / widok jest wciąż imponujący". Wyprawa i postawa flâneura, za którego trzeba uznać podmiot, charakteryzuje się dążeniem do przywrócenia dawnego architektonicznego ładu, a przynajmniej potrzebą zaświadczenia o jego minionym istnieniu. Nieustannie angażowane oko i pamięć pozwalają na mentalną rekonstrukcję przestrzeni, ale także-jako kategorie poetyckie - uczestniczą w literacko-antropologicznym projekcie restytucji przeszłości, stając się ośrodkami sytuacji lirycznej. Opis doświadczenia, a zwłaszcza jego naoczności, powoduje, że liryka pełni tutaj funkcję skryptu pamięci ${ }^{46}$. Ów skrypt zawiera zbiór wiedzy na temat sekwencji zdarzeń czy działań, których oczekuje się w danych okolicznościach. W wierszu schemat zdarzenia zakłada stałość widoku i zachowań obserwatorów.

${ }^{42}$ R. M i e 1 h o r s k i, Ewy Lipskiej podróże (w poszukiwaniu wartości). „Teksty Drugie” 2003, nr 2/3. Warto zauważyć, że Nowy Jork był już bohaterem i tematem twórczości E. L i p s k i e j, np. poematu Nowy Jork, miasto porwane (w: Nie o śmierć tutaj chodzi, lecz o biały kordonek. Kraków 1982).

${ }^{43} \mathrm{~L} . \mathrm{H}$ u 11, ,Meteorolodzy zapowiadaja zmierzch historii”- Ewa Lipska. W: Obecność nieprzynależna. Pokoleniowe wydziedziczenie w poezji po 1989 roku. Olsztyn 2010, s. 90.

${ }_{44} \mathrm{~J}$. P a s t e r s k i, ,Lektura istnienia”. O nowych wierszach Ewy Lipskiej. W zb.: Inna literatura? Dwudziestolecie 1989-2009. T. 2. Red. Z. Andres, J. Pasterski. Rzeszów 2010, s. 115.

${ }_{45}$ Zob. L. H u 11, Cykl retrospektywny - ,Wiersze amerykańskie” Julii Hartwig. W zb.: Polski cykl liryczny. Red. K. Jakowska, D. Kulesza. Białystok 2008. Zob. też A. G1 e ń, Mądrość szeptu. Notatki o „Wierszach amerykańskich” Julii Hartwig. „Topos” 2004, nr 3/4.

${ }^{46}$ Zob. M. Te li c k i, Liryka jako skrypt pamięci. W: Poetycka antropologia Julii Hartwig. Poznań 2009. 
Późniejsze wersy utworu wyraźnie kontrastują z wcześniejszymi, opozycyjność buduje już spójnik, rozpoczynający konfrontatywną część:
Ale tu gdzie wznosiły się dwa siostrzane wierzchołki World Trade Center
wzrok nie chce pogodzić się z pustką
i rysuje w powietrzu znajome kontury.
Przestrzeń między wieżami wypełnia
ocalone przed wybuchem blade niebo,
pod którym wydaje się trwać nieustanny ruch zdruzgotanych wind,
bezgłośnie pracują setki komputerów,
przezroczyste cienie podają sobie $\mathrm{z}$ rąk do rąk
nietknięte pożarem dokumenty,
z telefonów płyną sygnały,
które odsłuchane będą być może za miliony lat
na jakiejś nieznanej planecie.

W konstrukcji obrazu stosuje Hartwig poetykę negatywną, opartą na braku. Dawny pejzaż powoływany do ponownego zaistnienia stanowi szkic czyniony z pamięci, to w niej zdeponowana jest ukryta modalność obrazu. Ejdetyczna wyobraźnia ujawnia swoją odtwórczą siłę, a pejzaż odtworzony daleki jest tu od wizji arkadyjskiej ${ }^{47}$. Przestrzeń ulega amplifikacji, otwiera się na nowe, niedostępne rejony, jej chronotopia zakłada kontrfaktyczne istnienie innych wymiarów, wyzwalających nadzieję jakiegoś ocalenia (,,z telefonów płyną sygnały, / które odsłuchane będą być może za miliony lat / na jakiejś nieznanej planecie”). Rekonstruowany obraz ma charakter powidoku, wynika to z określonego percepcyjnego nastawienia podmiotu, który podejmuje próbę aktualizacji minionego.

Ukryty autobiografizm utworu Wieże jawi się jako suma opisanych doznań, topografii miejsca. Odnosząc się właśnie do nowszych wierszy Hartwig, Hull mówi:

Autobiograficzne projekcje Hartwig w pewnym stopniu zapewne służą celom autoterapeutycznym, ale szersza obecność wątków retrospektywnych pozbawiona jest elementu egocentrycznego - przywoływanie wspomnień widzi raczej jako powinność wobec świata zewnętrznego, ludzi, którym coś zawdzięcza, miejsc ważnych w jej życiu ${ }^{48}$.

- i w innym miejscu badaczka dodaje: „Julia Hartwig traktuje pamięć jako zobowiązanie etyczne [...]" ${ }^{49}$. Wywiedziony z pamięci i uobecniony obraz przeciwdziała amnezji, oznacza potrzebę odbudowy sensu świata i niezgodę na znikanie jego śladów lub przynajmniej osłabienia tempa tego procesu. Tym bardziej że: „,To, co pamiętamy, jest efektem pracy nad własną tożsamością; ta jest naniesionym na kanwę zapamiętanych faktów obrazem własnej biografii" ${ }^{50}$. Wieże stanowią więc „formę pamiętania" ${ }^{51}$ o innych, ale także o sobie i o konkretnym miejscu.

${ }^{47}$ Arkadyjskość pejzaży poetki zauważa L. Hu 11 (Arkadyjskie pejzaże Julii Hartwig. W zb.: Święte miejsca w literaturze. Red. Z. Chojnowski, A. Rzymska, B. Tarnowska. Olsztyn 2009).

${ }^{48}$ L. H u 11, „Bądź wdzięczna, bytaś hojnie obdarzona” - Julia Hartwig. W: Obecność nieprzynależna, s. 192.

49 Ibidem, s. 197. J. H a rtwig (Zapis nowojorski. Przedmowa w: L. Głó w c z e w s ka, Nowy Jork. Kartki z metropolii. Warszawa 2004) wraca do nowojorskich wydarzeń także w wypowiedziach stanowiących składnik cudzych publikacji.

${ }_{50}$ J. Mikułowski Pom orski, Ogród niepamięci. W: M. A u gé, Formy zapomnienia. Przeł. A. Tu r c zy n. Kraków 2009, s. 8-9.

${ }^{51}$ Określenie to stanowi antytetyczną transformację tytułu książki A u g é g o Formy zapomnienia. 
W związku z poetyką oka i pamięci u autorki Bez pożegnania możliwe byłoby też poszerzenie kategorii ,zatartych miejsc” stosowanej przez Annę Kałużę i odnoszonej przez badaczkę głównie do wierszy z tomu Zobaczone:

Nietrudno objaśnić znaczenie figur zasłonięcia, które występują w twórczości Hartwig. Wiążą się one z dualistycznym postrzeganiem świata. Z jednej strony, za niemożność zobaczenia tego, co zakryte, odpowiada perspektywa metafizyczno-epistemologiczna, w przypadku której poetka uznaje skończoność, ale nie błędność ludzkiego poznania; z drugiej - decyduje o tym psychologiczna postawa odmowy patrzenia i - dające się tak samo thumaczyć - uczucie ulgi z powodu utraty wzroku $[\ldots]^{52}$.

Możliwość, która rysuje się w wierszu, dotyczy wysiłku i konieczności wizualizacji nie istniejących już obiektów ${ }^{53}$, widzenie i pamięć są ze sobą sprzężone. Szkicowane w ten sposób obszary (także miasta widziane we śnie, jak np. w utworze Widziałam, również z tomu Bez pożegnania ${ }^{54}$ ) mogą być traktowane jako ekwiwalenty realnych przestrzeni. Dynamika pamięci warunkowana jest u Hartwig modelem przeżywania i postrzegania świata. Światopoglądowy dystans, jaki dzieli debiutancki tom Pożegnania od zbioru Bez pożegnania, świadczy o pewnym przeformułowaniu nastawienia do otaczającej rzeczywistości, świadomość przemijania łączy się teraz z nadzieją na ponowne spotkanie minionego, charakteryzuje się brakiem definitywnych rozstrzygnięć.

Przyjęte - przez autorki omawianych tu wierszy - strategie wypowiedzi oparte są na eufemistycznym komunikowaniu o wstrząsających wydarzeniach, łączy je poetyka stosowności, która w jakimś stopniu znosi pytania o prawo do przedstawiania nowojorskiej apokalipsy. Poprawa, analizując utwór Lipskiej, mówi o obnażaniu fałszu wszelkich retoryk, jakie się w nim dokonuje, i pyta: ,„Jak jednak możliwe jest napisanie tego wiersza - i jednocześnie pozostanie kimś wiarygodnym?" 55 Wiarygodność tę ustanawia i zarazem weryfikuje metajęzykowy charakter wypowiedzi poetyckiej. Dylematy etyczne są częścią profesji artystycznych. Agnieszka Ogonowska mówi o tym w kontekście wpływu współczesnych netokratów na życie i władzę:

Z jednej strony, twórcy literatury, występując w roli komentatorów społecznych, sytuują się po stronie netokracji, gdyż ustalają obowiązującą definicję świata, z drugiej - sami, podle-

52 A. K a ł u ż a, Julia Hartwig: estetyzacje. Metafora ,zatartych miejsc”. W: Wola odróżnienia. O modernistycznej poezji Jarosława Marka Rymkiewicza, Julii Hartwig, Witolda Wirpszy i Krystyny Miłobędzkiej. Kraków 2008, s. 138.

${ }_{53}$ Specyficzną wizualizację proponuje cytowany już w artykule J. B a u drillard (Requiem dla Twin Towers. W: Duch terroryzmu, s. 44-45), w narracji próbuje uwzględnić optykę terrorystów, ale zdradza też fascynację niesamowitością sytuacji, monumentalnym spektaklem grozy: „Zawalenie się wież jest wydarzeniem symbolicznym wielkiej wagi. Wyobraźcie sobie, że wieże nie zawaliły się wcale albo że zawaliła się tylko jedna: efekt w żadnym razie nie byłby taki sam. Dowód kruchości globalnej potęgi nie byłby tak olśniewający. Wieże były i pozostały emblematem tej potęgi aż do swego dramatycznego końca, który przypomina akt samobójczy. Widząc, jak się zapadają, jakby na skutek implozji, odnosiło się wrażenie, że w odpowiedzi na samobójstwo samolotów samobójców wieże same też popełniły samobójstwo".

${ }^{54} \mathrm{H}$ a r tw i g, Bez pożegnania, s. 85. Chociaż w tym przypadku - w porównaniu z utworem Wieże - mamy do czynienia $\mathrm{z}$ odwróceniem procesu widzenia. Podmiot najpierw ogląda miasta w snach, a dopiero potem ,na własne oczy”. Jednak i tu, jak w przypadku pamięci miejsca w Wieżach, topograficzna przedwiedza wyniesiona ze snów w konsekwencji okazuje się silniejsza.

${ }^{55}$ Popraw a, op. cit., s. 194. 
gając prawom rynku, choćby w zakresie automarketingu związanego z ochroną własnych interesów, stoją po stronie podporządkowanych nowej elicie władzy ${ }^{56}$.

Liryki Szymborskiej i Lipskiej dotyczą pośrednictwa mediów w przedstawianiu wydarzeń, obraz i słowo stają się tutaj jednocześnie przedmiotami i instrumentami poznania. Można przyjąć, że obie poetki występują w roli „strażników społeczno-kulturowego konsensusu, regulatorów społecznego dialogu, kontrolerów wartości i znaczeń nadawanych poszczególnym obiektom kulturowym" ${ }^{57}$. Natomiast utwór Hartwig otwiera się na „widzenie empatyczne" ${ }^{58}$ i skłania do niego także odbiorcę. Zachodzi w nim poetyckie kryptonimowanie daty, której deszyfracja w lekturze odbywa się z obiektów pośrednio sygnalizowanych w deskrypcji i z ich cech, faktów. We wszystkich wierszach zawiera się nieakceptacja zmian będących wynikiem agresji: tragicznej śmierci spadających z wieżowców osób, świata, który „się spruł”, braku w urbanistycznym pejzażu charakterystycznych budowli, których zniszczenie pogrzebało wiele istnień ludzkich. Utwory trzech poetek charakteryzuje gest powstrzymania się, powściągliwość reakcji podmiotu. Tkwi w tych wierszach potencja dialogu ${ }^{59}$ ze względu na wagę poruszanych spraw i metakomunikacyjne sygnały tekstowe, dotyczące sposobu mówienia o drastycznych wydarzeniach i ludzkim cierpieniu oraz wyboru środków artystycznych do tego celu. Trzy wiersze współtworzą ,,szibboletową” konstelację tekstów, w której „wiele heterogenicznych pojedynczości zapisuje się razem w usianej licznymi gwiazdami konfiguracji jednego jedynego datowanego znamienia" ${ }^{60}$.

Abstract

KATARZYNA WAQDOLNY-TATAR

(Pedagogical University of Cracow)

\section{SEPTEMBER 11 ${ }^{\mathrm{TH}}, 2001$ IN POETRY (SZYMBORSKA, LIPSKA, HARTWIG)}

The article relates to the events of September $11^{\text {th }}, 2001$ recorded in the poems by Wisława Szymborska, Ewa Lipska, and Julia Hartwig. The date indicates as well as encodes the dramatic events connected with World Trade Center terrorist attack. It can be interpreted and described using Jacques Derrida's term "shibboleth." The arrangement of the poems under analysis reveals a temporal aspect expressing a different distance to the tragedy, namely "here and now" (Szymborska), "shortly after" (Lipska) and "some time later" (Hartwig). In Szymborska, the medium of photography determines the verbal projections of images, while literature settles the photography's scope of reference. The photography, to continue, can be seen as a fake ekphrasis. Referring to the methods of communication about the events in question, Lipska juxtaposes two perspectives, namely the vision

${ }^{56}$ A. O g o n o w s k a, Netokracja wobec literatury. W: Twórcze metafory medialne, s. 187.

57 Ibidem, s. 200. Mimo iż autorka charakteryzuje w ten sposób krytyków, to jednak z racji struktury obu wierszy i ich wymowy - uwagi te wydają się odpowiednie również w odniesieniu do poetek.

58 To określenie A. L e g e ż yń s ki e j (Uważność - wedlug Julii Hartwig. W: Od kochanki do psalmistki... Sylwetki, tematy i konwencje liryki kobiecej. Poznań 2009). O zbiorze Bez pożegnania wypowiada się również M. C z e r m i ń s k a (Żyjąc zyskujemy życie. O późnych wierszach Julii Hartwig. W: Księga Janion. Oprac. Z. Majchrowski, S. Rosiek. Gdańsk 2007).

${ }_{59}$ M.in. o dialogowości wierszy Lipskiej w szerszym kontekście pisze P. Mich ałowski (W poetyckim teatrze mowy Ewy Lipskiej. W zb.: Dramatyczność i dialogowość w kulturze. Red. A. Krajewska, D. Ulicka, P. Dobrowolski. Poznań 2010).

${ }^{60}$ D e r rid a, op. cit., s. 40. 
(per)formed in mass media and by various social commentators, and that of an ordinary man (a tailor). Both form contrasting commentaries on the reality. Hartwig's poem does not indicate its connections to September $11^{\text {th }}, 2001$; it is only later that the presented lyrical situation and geographical-topographical details allow for the disclosure. Wieże (Towers) prompt into reflection on the absence of those monumental buildings in New York's urban landscape which, when destroyed, caused the deaths of many people. The poetics of eye and memory is a literary restoration of the old picture as well as everyday habits after the disaster. The poetic experience of the date is realised with different creative strategies, all of them being the results of searching for the modes of speaking about the tragedy. Three poems shape a shibboleth composition with the date in its semantic centre. 